\title{
FOREIGN INVESTMENT ARBITRATION: A PLACE FOR HUMAN RIGHTS?
}

\author{
BRUNO SimMA*
}

\begin{abstract}
The protection of foreign investment by way of treaties and arbitration has recently suffered attacks on its legitimacy. The article turns on human rights concerns in this context and analyses what legal mechanisms and arguments can be employed to ease the tension between investment protection and human rights. Harmonization in this regard finds two key entry points: first, at the inter-State level of investment agreements, and secondly, at the intra-State level of the foreign investment contract. At the first level, human rights considerations, particularly concerning economic and social rights, can be brought to bear by way of their systematic integration qua treaty interpretation. The article subjects this inroad to close scrutiny but concludes that, while it possesses considerable merits and has attracted a certain attention (albeit still more in the academic world than in that of arbitration practice), it remains an approach ex post, possibly leaving excessive discretion to arbitrators. Thus, at the second level, already at the pre-investment stage, efforts should be made to recast investors' "legitimate expectations" under foreign investment contracts by including a "human rights audit" as part of the due diligence to be conducted by the investor and the host State, to survey the host State's human rights treaty commitments and domestic methods for implementing these commitments. The primary objective of this audit would thus be to fully include the prospective host State's international obligations as part of the body of applicable law and thus create a better map of the landscape of an investor's "legitimate expectations".
\end{abstract}

\section{INTRODUCTION}

According to the authors of a recent essay published in a book entitled 'The Backlash against Investment Arbitration', the current system of investment arbitration 'seems to be leaning toward separation of human rights and investor's rights like oil and water'. 'Let me take this comparison as a kind of

* Judge at the International Court of Justice; Professor at the University of Munich (retired); William H Cook Global Law Professor at the University of Michigan Law School Ann Arbor (on leave). This text is based on the Grotius Lecture delivered in London on 3 March 2011. My thanks go to Diane A Desierto (LLM, JSD, Yale Law School Fellow), my University Trainee at the Court 2010-2011, for her valuable assistance.

1 M Toral and T Schultz, 'The State, a Perpetual Respondent in Investment Arbitration? Some Unorthodox Considerations', in M Waibel, A Kaushal, K-H Liz Chung, and C Blachin (eds), The Backlash Against Investment Arbitration: Perceptions and Reality (Kluwer Law, The Hague, 2010) 577-602. 
working hypothesis. It certainly does not agree well with a Leitmotiv in my own more recent academic work: that of the impact of human rights on the development of international law. ${ }^{2}$ Oil and water do not mix, at least not readily. Is this also true of human rights and the protection of foreign investment-here also in the sense that they ought to be kept apart? Some observers, or rather stakeholders, might think so. There is, of course a way to overcome this separation: science and industry employ some sort of mediators between the water and the oil (so-called 'emulgators') ${ }^{3}$ to achieve this. To translate this into the relevant 'experimental' questions for our Grotian purposes is to ask how we can mediate the tension between investment protection and human rights concerns. What legal mechanisms and arguments may we employ to assure a harmonious interface of the two? What are possible, and acceptable, legal avenues for an international investment tribunal to consider international human rights law in investor-state disputes?

Before I turn to answer these questions, let me state the reasons why I think that they are relevant. First, the positive side: the protection of foreign investment by way of treaties is one of the great international legal success stories. ${ }^{4}$ While we don't really seem to know whether, and eventually in what measure, it has been responsible for the huge increase in foreign investment in our globalized world (with more than a trillion dollars involved), international investment protection as such has developed into a growth industry, with several multi-or plurilateral systems in place (NAFTA, CAFTA, ASEAN, the European Energy Charter), but even more staggering, with now close to 3,000 bilateral investment treaties in force worldwide, for around 170 countries, Germany alone having concluded about 150 of them. ${ }^{5}$ With these treaties there has occurred what can only be called an explosion of international

2 See in particular B Simma, From Bilateralism to Community Interest in International Law, Recueil des Cours (1994-VI), vol 250, 217-384; B Simma, 'International Human Rights and General International Law: A Comparative Analysis', 2 Collective Courses of the European Academy of European Law 225 (1994/IV); B Simma, Human Rights Before the International Court of Justice: Community Interest Coming to Life? (forthcoming in Festschrift in honour of Rüdiger Wolfrum).

3 JW Gooch (ed), Encyclopedic Dictionary of Polymers (2 $2^{\text {nd }}$ edn, Springer, 2010) 265.

4 KJ Vandevelde, 'A Brief History of International Investment Agreements' in KP Sauvant and LE Sachs (eds), The Effect of Treaties on Foreign Direct Investment: Bilateral Investment Treaties, Double Taxation Treaties, and Investment Flows (OUP, Oxford, 2009) 1-35.

5 See United Nations Conference on Trade and Development, 'Latest Developments in Investor-State Dispute Settlement, IIA Issues Note No. 1 (2011) < http://www.unctad.org/en/ docs/webdiaeia20113_en.pdf $>$ accessed 15 April 2011; United Nations Conference on Trade and Development, 'Latest Developments in Investor-State Dispute Settlement', IIA Issues Note No. 1 (2010) < http://www.unctad.org/en/docs/webdiaeia20103_en.pdf > accessed 15 April 2011; United Nations Conference on Trade and Development, 'Recent Developments in International Investment Agreements (2008-June 2009)', IIA Monitor No. 3 (2009) < http://www.unctad.org/ en/docs/webdiaeia20098_en.pdf > accessed 15 April 2011; United Nations Conference on Trade and Development, 'Recent Developments in International Investment Agreements (2007-June 2008)' IIA Monitor No. 2 (2008) < http://www.unctad.org/en/docs/webdiaeia20081_en.pdf> accessed 15 April 2011. 
investment arbitration, with ICSID alone registering 331 cases as of December of last year. ${ }^{6}$

What is not such good news is that this awesome edifice has more recently developed some visible cracks. We are confronted with claims of a lack of balance leading to apprehension, disillusionment and disappointment on the part of participants - voiced not just by left-wing regimes in Latin America or the usual suspects among the NGOs but, for instance, also by US presidential candidates in their electoral campaigns. ${ }^{7}$ So, do we face something like a legitimacy crisis, particularly in investment protection by international investment agreements (IIAs)? In their practical application, do such IIAs unduly favor the investor, often the mighty transnationals? The statistics of ICSID do not confirm these suspicions; neither does empirical analysis by authors such as Susan Franck, ${ }^{8}$ but all this cannot dispel doubts. The criticism has been fuelled, for instance, by the situation of Argentina against which alone more than 50 arbitrations have been brought. To point at a few further crisis symptoms: the stance of Bolivia in the Aguas del Tunari case ${ }^{9}$ as well as Bolivia and Ecuador now having left ICSID altogether $;{ }^{10}$ Nicaragua is openly advocating doing so; Ecuador has gone as far as rejecting the idea of foreign investment arbitration in its constitution and precluding the possibility of future treaties that would confer jurisdiction over investor-state disputes to arbitral tribunals outside Latin America. ${ }^{11}$

Concerns have been raised not only by States that find themselves 'at the receiving end' of the system. They are voiced less by the investment arbitration 'in-group', which is understandable, than by civil society, the NGO community, and academia. Of course, such concerns do not relate to human rights only but these are certainly, and prominently, included. To quote just

${ }^{6}$ International Centre for Settlement of Investment Disputes, The ICSID Caseload-Statistics (Issue 2011-1), <http://icsid.worldbank.org/ICSID/FrontServlet?requestType=ICSIDDocRH\& actionVal=ShowDocument\&CaseLoadStatistics $=$ True\&language=English11 $>\quad$ accessed 14 April 2011.

7 See A Beattie, 'Concern Grows over Global Trade Regulation' Financial Times (London England 12 March 2008), <http://www.ft.com/cms/s/0/58699264-ef9c-11dc-8a170000779fd2ac,s01=1.html\#axzz1LHVqkfs8 > accessed 3 May 2011.

${ }^{8}$ SD Franck, 'Development and Outcomes in Investment Arbitration' (2009) 50 Harv Int'1 L J 435; SD Franck, 'Considering Recalibration of International Investment Agreements: Some Empirical Insights' in JE Alvarez, KP Sauvant, K Gerard Ahmed, G Vizcaino (eds), The Evolving International Investment Regime: Expectations, Realities, Options (OUP, Oxford, 2011).

9 Aguas del Tunari SA v Republic of Bolivia [2005] ICSID Case No ARB/02/3, Jurisdiction, 20 ICSID Rev Foreign Investment LJ 450.

${ }^{10}$ United Nations Conference on Trade and Development, 'Denunciation of the ICSID Convention and BITs: Impact on Investor-State Claims', IIA Issues Note No. 2 (December 2010) $<$ http://www.unctad.org/en/docs/webdiaeia20106_en.pdf > accessed 3 May 2011.

${ }_{11}$ MH Mourra, 'The Conflicts and Controversies in Latin American Treaty-Based Disputes' in MH Mourra and TE Carbonneau (eds), Latin American Investment Treaty Arbitration: The Controversies and Conflicts (Kluwer Law, The Hague, 2008) 16; J Briones and A Tagvoryan, 'Is International Arbitration in Latin America in Danger?' (2010) 16 Law \& Bus Rev of the Americas 131, 132. 
one critical voice: in a recent collection of essays dedicated to our topic, Professor Francesco Francioni asks 'whether the far-reaching penetration of foreign investment guarantees into areas of national regulation of public interests should not be counterbalanced by corresponding opportunities for access to justice and the availability of remedies for civil society in the host State of foreign investments'. ${ }^{12}$

With these observations I hope to have proven that the two experimental questions I asked above are pertinent. Let me now proceed to answering them and submit, as a first point, as a matter of policy, that international investment protection and human rights are not 'separate worlds'. They are not as foreign to each other as some make it appear, preferring to see this branch of the law as a cluster of more or less de-politicized 'self-contained regimes', ${ }^{13}$ splendidly isolated from the dynamics and tensions of the rest of the legal universe, including human rights. After all, the ultimate concern at the basis of both areas of international law is one and the same: the protection of the individual against the power of the State.

But also in economic terms, foreign investment and human rights are not to be seen as separate as it might appear at first glance. One of the more comprehensive empirical studies on the 'bite' of BITs has shown that their success in actually attracting foreign investment depends to a considerable degree upon the political environment in a potential host State $;{ }^{14}$ rule of law and respect for human rights in tandem with investor protection can thus form a sort of virtuous circle in improving welfare.

Despite such attempts at reconciling the two matters, however, I still sense quite a bit of reticence, Berührungsangst, vis-à-vis human rights within the foreign investment protection/arbitration profession. This might be in the investment arbitrators' genes, because what is probably the large majority of them has a private or commercial law rather than a public law or public international law background and might thus tend to see international human rights as a potential, or probable, cause of political disturbances, intruding in their 'purely legal', autonomous field, with its ground rules being determined by neo-liberal thought. ${ }^{15}$ In a way, this is not hard to understand, because,

${ }^{12}$ F Francioni, 'Access to Justice, Denial of Justice, and International Investment Law' in P-M Dupuy, F Francioni and E-U Petersmann (eds), Human Rights in International Investment Arbitration (OUP, Oxford, 2009); quote taken from abstract of original article published in (2009) 20 EJIL 3, 729-747.

13 See B Simma, 'Self-contained Regimes' (1985) 16 Neth Ybk Intl L 111-136; B Simma and D Pulkowski, 'Of Planets and the Universe: Self-Contained Regimes in International Law' (2006) 17 EJIL 3, 483-529.

${ }^{14} \mathrm{~J}$ Tobin and S Rose-Ackerman, 'When BITs have some bite: The political-economic environment for bilateral investment treaties' (2006) 6 The Review of International Organizations $1-32$.

${ }^{15}$ For differing views on the effect of neo-liberal thinking on the international investment regime, see KJ Vandevelde, 'Sustainable Liberalism and the International Investment Regime' [1997-1998] 19 Mich J Int'l L 373; M Sornarajah, 'Toward Normlessness: the Ravage and 
after all, protection of foreign investment is to benefit the investor, while human-rights-based claims, if and when they arise in investment disputes, will mainly appear as defenses argued by States that have interfered in such investments. Let me say already at this point that the conclusion I draw from this is to also explore, and put the emphasis on, entry points for human rights which appear much earlier in our legal scenario, before disputes have a chance to arise, namely at the stage of the negotiation of the individual foreign investment contract.

My focus here will be on some fundamental questions that I consider not satisfactorily explored, and leave several other relevant matters unaddressed, among them corporate responsibility for human rights violations, ${ }^{16}$ the amicus curiae issue or the impact of human rights law on access to information for the transparency of investment arbitration, ${ }^{17}$ or lack thereof. I can only mention in passing the impact of the extension of exclusive European Union competence to foreign direct investment by the Lisbon Treaty. ${ }^{18}$ In this matter, many questions are keeping investment arbitrators nervous, but one thing is certain: in the years to come, the EU itself will proceed to conclude investment agreements with particularly important third countries, and we will then see whether, and how vehemently, the Union will bring to bear the core values it is committed to pursue also internationally, among them respect for human rights, in its relations with such key partners, not all of which being equally enthusiastic about human rights.

Retreat of Neo-liberalism in International Investment Law' in KP Sauvant (ed), Yearbook on International Investment Law \& Policy (OUP, Oxford, 2010) Part 2, no.16.

16 See among others M Jacob, 'International Investment Agreements and Human Rights', INEF Research Paper Series, on Human Rights, Corporate Responsibility and Sustainable Development 03/2010. Duisburg: Institute for Development and Peace, University of DuisburgEssen, <http://www.humanrights-business.org/files/international_investment_agreements_and_ human_rights.pdf $>$ accessed 15 April 2011; Jarrod Hepburn and V Kuuya, 'Corporate Social Responsibility and Investment Treaties' in M-C Cordonier Segger, MW Gehring, and A Newcombe (eds), Sustainable Development in World Investment Law (Kluwer 2010) 585-610.

${ }^{17}$ For recent literature on the subject, see N Bernasconi-Osterwalder, 'Transparency and Amicus Curiae in ICSID Arbitrations' in Segger, Gehring and Newcombe (n 16) 189-208; JE Viñuales and F Grisel, 'Amicus Intervention in Investor-State Arbitration: A Contemporary Reappraisal', American Arbitration Association and International Centre for Dispute Resolution, Handbook on International Arbitration and ADR (American Arbitration Association, $2^{\text {nd }}$ edn, October 2010) ch 34; E Levine, 'Amicus Curiae in International Investment Arbitration: The Implications of an Increase in Third-Party Participation' (2011) 29 Berkeley J Int'l L 1, 200-224; J Harrison, 'Human Rights Arguments in Amicus Curiae Submissions: Promoting Social Justice?' in Dupuy, Francioni, and Petersmann (n 12) 396-420.

18 See S Woolcock and J Kleinheisterkamp (Jan 2010) The EU approach to international investment policy after the Lisbon Treaty. EXPO/B/INTA/FWC/2009-01/Lot7/07-08-09. European Parliament, Brussels, Belgium; Nikos Lavranos, New Developments in the Interaction between International Investment Law and EU Law, (2010) 9 The Law and Practice of International Courts and Tribunals, 409-441. 


\section{INVESTMENT LAW}

Investment law practitioners might tend to regard the importance of human rights issues in international investment law as overstated. And while it is true that in the last decade or so there has developed a robust scholarly debate on the interface between human rights and international investment law, ${ }^{19}$ in practice human rights-based claims have not overrun the dockets of foreign investment arbitral tribunals. ${ }^{20}$ To investment practitioners, it might thus appear that international human rights fulfil no more than an ancillary role in the settlement of investor-state disputes, ${ }^{21}$ manifested in the few known instances when arbitrators '[have] look[ed] to human rights law for analogies or as an aid in constructing the meaning of the investment treaty obligations. ${ }^{22}$ I would submit, however, that this is a myopic way of looking at our subject. ${ }^{23}$ Nowadays, human rights compliance is a priority in any decent host State's public policy agenda and thus it cannot but affect the regulatory spaces of a host State vis-à-vis foreign investors and other States. The current 'thinness' of jurisprudence involving direct clashes between treaty norms on human

19 P-M Dupuy, 'Unification Rather than Fragmentation of International Law? The Case of International Investment Law and Human Rights Law' in Dupuy, Francioni \& Petersmann (n 12) $45-62$.

20 See United Nations Conference on Trade and Development, 'Selected Recent Developments in IIA Arbitration and Human Rights', IIA Monitor No. 2 (2009) International Investment Agreements, at p. 3 ('In practice, however, human rights issues have been relatively slow to arise in the IIA arbitration context. Indeed, IIAs themselves are generally silent with respect to human rights matters, and do not expressly reference human rights-related obligations of States, much less seek to introduce any new human rights duties or obligations for governments or investors. For their part, governments have rarely articulated clear views as to the relationship between IIAs and human rights...') < http://www.unctad.org/en/docs/webdiaeia20097_en.pdf > accessed 3 May 2011; C Reiner and C Schreuer, 'Human Rights and International Investment Arbitration' in Dupuy, Francioni \& Petersmann (n 12) 82-96.

21 See H Mann, International Investment Agreements, Business and Human Rights: Key Issues and Opportunities, (International Institute for Sustainable Development, February 2008), 25-29. For relevant arbitral case law see Mondev International Ltd $v$ United States of America, ICSID Case No. ARB/(AF)/99/2, Award of October 11, 2002, para. 144; Técnicas Medioambientales Tecmed, SA v United Mexican States, ICSID Case No ARB (AF)/00/2, Award of May 29, 2003, at paras 116-122; Azurix Corp v The Argentine Republic, ICSID Case No. ARB/01/12, Award of July 14, 2006, paras. 311-312; Methanex v United States of America, (NAFTA/UNCITRAL) Final Award of 3 August 2005; CMS Gas Transmission Company v The Argentine Republic, ICSID Case No. ARB/01/8, Award of May 12, 2005, paras 114-121.

22 LE Peterson, Human Rights and Bilateral Investment Treaties: Mapping the role of human rights law within investor-state arbitration (Rights \& Democracy, International Centre for Human Rights and Democratic Development, 2009) $25<$ http://www.dd-rd.ca/site/_PDF/publications/ globalization/HIRA-volume3-ENG.pdf $>$ accessed 3 May 2011.

${ }^{23}$ On the broad impact of international investment arbitration on international governance, administrative networks, and international relations, see JW Salacuse, 'The Emerging Global Regime for Investment' (2010) 51 Harvard J Int'1 L 2, 427-473; G van Harten and M Loughlin, 'Investment Treaty Arbitration as a Species of Global Administrative Law', (2006) 17 EJIL 1, 121-150; S Schill, The Multilateralization of International Investment Law (CUP, Cambridge, 2009) 3-18. 
rights and investment should not deceive us into believing that this is merely a controversy at the fringes of international investment law.

That the inherent long-term nature of foreign investment contracts will implicate the host State's international duties stemming from economic and social rights appears to me inevitable. Such contracts span decades, outlast the administrations that entered into them, and often encompass a vast range of the State's economic activities - from the delivery of basic services to privatization of State-owned enterprises and utilities; physical and telecommunications infrastructure; government procurement; natural resource exploration and extraction activities, among others. At the same time, most host States will be parties to the International Covenant on Economic, Social and Cultural Rights and must live up to their duties under the Covenant to progressively realize obligations to 'respect, protect, and provide' these rights within their jurisdictions. I will look into this in a moment.

The tension between investment protection and human rights thus translates into a problem of aiming at two 'moving targets': for the foreign investor, how to accurately estimate the political risks of the investment before, or at the time of, its establishment in the host State so as to enable the investor to 'price' the contract cost correctly according to its projected returns on investment; and for the host State, how to determine the optimal degree of police powers and regulatory authority to be retained during the life of the investment, needed to perform its international human rights obligations. ${ }^{24}$

The problem is that the present architecture of international investment dispute settlement cannot adequately respond to this challenge. ${ }^{25}$ The

${ }^{24}$ In the present era of foreign investment which is increasingly being linked to more comprehensive regional and multilateral trade umbrellas, this problem of 'moving targets' between investment protection and compliance with economic and social rights does not appear solely in the traditional North-South binary of 'capital-exporting' developed States and 'capital-importing' developing States, but also to South-South and North-North trade cooperative structures and investment relationships. For a description of these trends in investment treaty rulemaking, see United Nations Conference on Trade and Development, Investor-State Dispute Settlement and Impact on Investment Rulemaking (2007), 3-9 < http://www.unctad.org/en/docs/iteiia20073 en.pdf $>$ accessed 4 May 2011; S Rose-Ackerman, 'The Global BITs Regime and the Domestic Environment for Investment' in Sauvant and Sachs (n 4) 311-321. In the past decade, developing economies have also become sources of foreign investment for the least developed countries (LDCs). See United Nations Conference on Trade and Development, Foreign Investment in LDCs: Lessons Learned from the Decade 2001-2010 and the Way Forward (2011) $10<\mathrm{http}$ // www.unctad.org/en/docs/diaeia2011d1_en.pdf > accessed 4 May 2011.

${ }_{25}$ Remedies include arbitration (institutional and ad hoc), which is automatically enforced by national courts of States parties to either the 1965 Convention on the Settlement of Investment Disputes between States and Nationals of Other States (otherwise known as the ICSID Convention) and the 1958 New York Convention on Recognition and Enforcement of Arbitral Awards (for UNCITRAL and other non-ICSID arbitrations). Other dispute settlement mechanisms include conciliation, mediation, fact-finding boards, and direct negotiations. For an analysis of the policy considerations and substantive features of these various mechanisms, see United Nations Conference on Trade and Development, Investor-State Disputes: Prevention and Alternatives to Arbitration (2010) 10-64 < http://www.unctad.org/en/docs/diaeia200911_en. pdf $>$ accessed 4 May 2011; R Doak Bishop, J Crawford, and WM Reisman, Foreign Investment Disputes: Cases, Materials, and Commentary (Kluwer Law, The Hague, 2005) 317-490. 
remedies provided in the system as it stands essentially only become available ex post. However, once the problem has arisen for the host State and the foreign investor, the 'moving targets' problem is simply reduced to an issue of compensability - namely, whether an investor is entitled to 'prompt, adequate, and effective compensation', following a substantial deprivation of his investment through a measure that a host State considers necessary to implement its international obligations. The host State will have to decide whether to pay off a foreign investor, for regulatory measures that do encroach on international investment obligations, but which are designed to ensure observance of international human rights obligations. Even if the host State were to win its dispute with the foreign investor over such regulatory measures, the duration and expense incurred from such a settlement might still cause 'regulatory chill' in the future, in the sense that the host State would self-censor or limit the possible measures by which it might have otherwise tried to implement international human rights obligations. Should host States choose not to submit themselves to dispute settlement, their policy options might shift towards either piecemeal renegotiation of investment treaties, or in more extreme cases, outright treaty denunciation. ${ }^{26}$ In any event, these processes entail time and expense for States in both diplomatic leveraging and diverting political capital. ${ }^{27}$

What is desirable, indeed necessary, therefore is that host States and foreign investors must mutually consider other strategies available within the framework of the international investment regime to harmonize investment protection with human rights compliance. These objectives need not be incompatible. ${ }^{28}$ I would submit that the task of harmonizing investment protection and compliance with obligations deriving from internationally guaranteed economic and social rights can be viewed, and undertaken, from two key entry points in the international investment regime, namely (1) the inter-state level, that is, the international investment agreement; and (2) the intra-state level of the foreign investment contract. ${ }^{29}$ Let me turn first to the international investment agreement as an entry point and discuss how international human rights can be made operational through treaty

\footnotetext{
26 See United Nations Conference on Trade and Development, 'Denunciation of the ICSID Convention and BITs: Impact on Investor-State Claims', IIA Issues Note No. 2 (December 2010) $<$ http://www.unctad.org/en/docs/webdiaeia20106_en.pdf > accessed 3 May 2011.

27 See J Salacuse and N P Sullivan, 'Do BITs Really Work? An Evaluation of BITs and their Grand Bargain' (2005) 46 Harv J Int'l L 67.

28 As we are reminded in the 2009 arbitral award in Phoenix Action Ltd v Czech Republic, investment protection 'should not be granted to investments made in violation of the most fundamental rules of protection of human rights ...'. Phoenix Action Ltd v Czech Republic, ICSID Case No ARB/06/5, April 15, 2009, para 78.

29 See S Kroll, 'The Renegotiation and Adaptation of Investment Contracts' in Norbert Horn and Stefan Kroll (eds), Arbitrating Foreign Investment Disputes: Procedural and Substantive Legal Aspects (Kluwer Law, The Hague, 2004) 425-470.
} 
interpretation. Thereafter, I will discuss the second entry point, much less debated in the literature, and put forward a proposal for accommodating these rights within the framework of the individual investment contract.

III. THE FIRST ENTRY POINT FOR HUMAN RIGHTS IN THE INTERNATIONAL INVESTMENT REGIME: THE INVESTMENT TREATY

Most of the literature on the topic of human rights and investment arbitration focuses on post-establishment approaches, primarily through an interpretation of investment treaty norms designed to accommodate human rights considerations. In turn, however, such interpretation is having an impact upon investment rule-making. In a 2007 Report, UNCTAD observes an innovative trend in the 'new generation' of renegotiated or recently concluded IIAs, where States are 'strik[ing] a balance between maintaining a comprehensive definition of investment... [and] address[ing] a broader range of issues... The protection of health, safety, the environment and the promotion of internationally-recognized labour rights are areas where new IIAs include specific language aimed at making it clear that the investment promotion and liberalization objectives of IIAs must not be pursued at the expense of other key public policy goals. ${ }^{30}$ Such recent innovations in IIAs have become possible through different means of intermediating human rights norms within the investment treaty framework, as (1) by including human rights treaties within the investment treaty's general provisions on governing or applicable law (eg, 'any relevant rules of international law applicable') ${ }^{31}$ (2) through the incorporation of specific human rights-based provisions into the investment agreement itself; ${ }^{32}$ and (3) through the interpretation of investment terms or concepts using human rights jurisprudence or treaty standards, on the basis of article 31(3)(c) of the Vienna Convention on the Law of Treaties. ${ }^{33}$ In the following, I will focus on the interpretation of investment law terms or concepts with reference to human rights treaty norms and jurisprudence.

30 United Nations Conference on Trade and Development, Investor-State Dispute Settlement and Impact on Investment Rulemaking (2007) $71<$ http://www.unctad.org/en/docs/iteiia20073_ en.pdf $>$ accessed 4 May 2011.

31 See similar or identical language in ICSID Convention art 42(1); North American Free Trade Agreement (NAFTA) art 1131; Energy Charter Treaty (ECT), art 26(6); Association of Southeast Asian Nations (ASEAN) Comprehensive Investment Agreement, art 40(1); JapanMexico Free Trade Agreement, art 84(1). Model BITs also contain similarly broad language. See 2004 Canada Model BIT, art 40(1); 2007 Colombia Model BIT art XI; 2008 Germany Model BIT art 7(1); 2003 India Model BIT art 12(1); 2004 US Model BIT arts 30(1) and (2); IISD Model International Agreement on Investment for Sustainable Development, art 48(1).

32 See 2004 Canada Model BIT, art 11 (Health, Safety and Environmental Measures); 2004 US Model BIT, art 12 [Investment and Environment] and art 13 [Investment and Labor].

33 B Simma and T Kill, 'Harmonizing Investment Protection and International Human Rights: First Steps Towards a Methodology' in C Binder, U Kriebaum, A Reinisch, S Wittich (eds), International Investment Law for the 21st Century: Essays in Honour of Christoph Schreuer (OUP, Oxford, 2009) 678-707. 


\section{A. Establishing a Relationship between Investment Treaties and Human Rights}

I think we will all agree that treaty interpretation by investment tribunals as an entry point is preferable to the belated (and possibly destabilizing) resort to 'human rights' as a 'public policy' ground for national courts to refuse recognition or enforcement of awards under the 1958 New York Convention or UNCITRAL Model Law. ${ }^{34}$ While domestic non-enforcement along these lines has not happened en masse, it remains a lingering threat from jurisdictions bent on resisting pro-investor arbitral awards. ${ }^{35}$

So, how can international human rights law inform treaty interpretation? The answer is not as simple as it might appear at first glance, because human rights law can only be taken into account if, and as far as, an investment tribunal is allowed to consider rules of international law whose source is not found in the treaty in question. In order for such 'external' rules to be admitted

\footnotetext{
${ }^{34}$ See 1958 New York Convention on Recognition and Enforcement of Arbitral Awards, art V(2)(b); UNCITRAL Model Law on International Commercial Arbitration, art 36; Pierre Lalive, 'Transnational (or Truly International) Public Policy and International Arbitration' ICCA Congress Series No. 3 Comparative Arbitration Practice and Public Policy in Arbitration (TMC Asser Instituut, ICCA, 1987); C Kessedjian, 'Transnational Public Policy' ICCA Montreal 2006, ICCA Proceedings (2006); World Duty Free Company Ltd. v. Republic of Kenya, ICSID Case No. ARB/00/7 (2006), paras 138-141; Plama v Bulgaria, ICSID Case No. ARB/03/24, 27 August 2008, paras 143-144; Final ILA Report on Public Policy as a Bar to Enforcement of International Arbitral Awards, 19 Arbitration International 2 (2004) 249-264; FA Mann, 'The Proper Law of Contracts Concluded by International Persons' (1959) 35 Brit YB Int'l L 34, 50. A Sheppard, 'Interim ILA Report on Public Policy as a Bar to Enforcement of International Arbitral Awards' 19 Arbitration International 2 (2003) 220, noting that ' "[i]nternational public policy' (rather than, simply, 'public policy') is increasingly referred to in legislation and court judgments. For example, in France, one of the limited grounds for refusing recognition or enforcement of an arbitral award is if it is contrary to 'ordre public international.' Portugal has a similar provision. The Court of Appeal of Milan has held that the public policy referred to in Article V.2(b) of the New York Convention is international public policy.' See also E Gaillard and J Savage (eds), Fouchard, Gaillard and Goldman on International Commercial Arbitration (Kluwer Law, The Hague, 1999), paras 1645-1662 ('The international public policy to which [the New French Code of Civil Procedure] refers can only mean the French conception of international public policy or, in other words, the set of values a breach of which could not be tolerated by the French legal order, even in international cases.'); L Mistelis, 'Keeping the Unruly Horse in Control, or Public Policy as a Bar to Enforcement of (Foreign) Arbitral Awards' (2000) 2 Int'l L F D Int'l 248, 252-253 ('The public policy referred to in the New York Convention is the public policy of the enforcing state. However, in applying their own public policy, state courts should give an international rather than a domestic dimension.')

35 The literature is rife with observations about the potential for abuse of the 'public policy' ground for denial of recognition and enforcement in art V(2)(b) of the 1958 New York Convention on Recognition and Enforcement of Arbitral Awards. See e.g, J Paulsson, 'The New York Convention in International Practice: Problems of Assimilation' in M Blessing (ed), The New York Convention of 1958: A collection of reports and materials delivered at the ASA conference held in Zurich on 2 February 1996 (Swiss Arbitration Association, 1996), at 108 (noting that it is art $\mathrm{V}$ which 'is most prone to misinterpretation and most open to abuse by national courts, displaying skepticism of non-national sources of law and bias against foreigners who wish to enforce awards in their territories'). In Russia, the public policy exception is a 'major issue,' due to a lack of uniform interpretation of the term: Patricia Nacimiento, 'Recognition and Enforcement of Arbitral Awards in Russia' (2010) 4 Journal of International Arbitration 294.
} 
to the scene at all, they must be placed in a particular relationship with the investment treaty concerned.

In the practice of international courts and tribunals, particularly of the ICJ and its predecessor, two such relationships have been established. The first one finds expression in the principle of evolutionary, or dynamic, interpretation: where treaties use 'known legal terms whose content the parties expected would change through time', 36 the meaning of these terms will be determined by reference to international law as it has evolved and stands at present, rather than to the state of the law at the time of the conclusion of the treaty. The interpretation by the ICJ of certain concepts prescribed in the Covenant of the League of Nations for the administration of Mandate territories, like 'well-being and development', in its Namibia Advisory Opinion of 1971 is a prominent example, ${ }^{37}$ followed by the Court in a number of subsequent judgments. ${ }^{38}$ For the European Court of Human Rights in Strasbourg, application of this principle is a matter of routine. ${ }^{39}$

The second relationship is expressed in the interpretative presumption that treaties are intended to produce effects which accord with existing rules of international law. ${ }^{40}$ This presumption is used to resolve issues of interpretation relating to the broader normative content of a treaty rather than to the meaning of a specific term. In the 2003 Oil Platforms Case, the ICJ employed the presumption that a clause contained in the 1955 Treaty of Amity etc, between the United States and Iran, designed to exempt the parties from such 'amity' in exceptional circumstances, was not intended to produce results that diverged from the general international law on the use of force. ${ }^{41}$ In this case,

36 Kasiliki/Sedudu Island (Botswana v Namibia) (Judgment) [1999] ICJ Rep 1045 (Declaration of Judge Rosalyn Higgins, para 2).

37 Legal Consequences for States of the Continued Presence of South Africa in Namibia (South West Africa) notwithstanding Security Council Resolution 276 (1970), Advisory Opinion, [1971] ICJ Rep 16, 28-30, paras 45-49.

38 See G Ress, Interpretation, in B Simma (ed), The Charter of the United Nations: A Commentary (2002) 13-32; Aegean Sea Continental Shelf (Greece v Turkey) (Judgment) [1978] ICJ Rep 3; Case concerning the Dispute Regarding Navigational and Related Rights, Judgment, [2009] ICJ Rep < http://www.icj-cij.org/docket/files/133/15321.pdf > accessed on 15 April 2011.

39 European Court of Human Rights, SE Golder v United Kingdom case (Appl. No. 4451/70), Report of the Commission (adopted on 1 June 1973), CE doc. D-60-355, Strasbourg, 1973, p 25, and Judgment of 21 February 1975, pp 9-12, paras 29-36. See Rudolf Bernhardt, 'Evolutive Treaty Interpretation, Especially of the European Convention on Human Rights' (1999) 42 German Yearbook of International Law 14; Alastair Mowbray, 'The Creativity of the European Court of Human Rights' (2005) 5 Human Rights Law Review 1, 57-79; Eva Brems, Human Rights: Universality and Diversity (Martinus Nijhoff, The Hague, 2001) 396-397.

${ }_{40}$ Case Concerning Right of Passage over Indian Territory (Preliminary Objections) [1957] ICJ Rep 142; Corfu Channel case (Judgment) [1949] ICJ Rep 24; Anglo-Iranian Oil Co case (Jurisdiction) Judgment of July 22 1952, [1952] ICJ Rep 104; H Lauterpacht, 'Restrictive Interpretation and the Principle of Effectiveness in the Interpretation of Treaties' (1949) 26 Brit Yb Int'1 L 67.

${ }^{41}$ Oil Platforms (Islamic Republic of Iran v United States of America) Judgment, [2003] ICJ Rep paras 73-78. 
the Court made express reference to article 31(3)(c) of the Vienna Convention on the Law of Treaties (VCLT). ${ }^{42}$ This presumption of coherence with existing international law is to be handled with care and on a case-by-case basis, because States might have concluded a treaty for the precise purpose of producing effects not in accordance with the law that was previously binding upon them; and States are free to do so, their liberty finding its limits in the presence of jus cogens (as was the case in Oil Platforms) or of certain multilateral obligations owed to third parties.

\section{B. Systemic Integration of Human Rights by Recourse to Article 31(3)(c) VCLT}

It is article 31(3)(c) of the Vienna Convention which covers both of the relationships opening the interpretation of an investment treaty to human rights considerations. According to this provision, in the interpretation of a treaty, there shall be taken into account, together with the context, 'any relevant rule of international law applicable in the relations between the parties'. Article 31(3)(c) has developed from a doctrinal wallflower, described as 'curious' by Professor McDougal around the time of its inclusion in the Vienna Convention, ${ }^{43}$ into a darling of recent international legal literature. It was termed no less than the 'master key to international law', by the International Law Commission, ${ }^{44}$ codifying the so-called 'systemic integration' of treaties, and is by now itself part of customary international law. As against such enthusiasm, I would advise keeping in mind what the provision was designed to be, namely a principle for the interpretation of treaties, nothing more. Defined as such, what can article 31(3)(c) yield as an entry point for international human rights law in the interpretation of an investment treaty? Again, and most importantly, it can only be employed as a means of harmonization qua interpretation, and not for the purpose of modification, of an existing treaty.

According to article 31(3)(c), whether international human rights law is a proper reference point from which to draw meaning for international investment agreements, depends on whether or not human rights constitute 'relevant rules of international law applicable between the parties' to such treaties. This formulation contains three elements that an external rule must fulfill in order

42 Oil Platforms (Islamic Republic of Iran v United States of America) Judgment [2003] ICJ Rep para 41.

${ }_{43}$ See M McDougal, HD Lasswell and JC Miller, The Interpretation of International Agreements and World Public Order: Principles of Content and Procedure (Martinus Nijhoff, The Hague, reprint 1994) 433-442.

44 This term was coined by ILC member (now ICJ Judge) Xue Hanqin during a more recent Commission debate on the significance of art 31(3)(c). ILC, Final Report of the Study Group on Fragmentation of International Law: Difficulties Arising from the Diversification and Expansion of International Law, para 420, UN Doc A/CN.4/L.682 (13 April 2006) (prepared by Martti Koskenniemi). 
to qualify for consideration under article $31(3)$ (c). The first is that we must actually have a 'rule' before us. The second is that this rule must be 'relevant'. The third is that the rule must be 'applicable in the relations between the parties'. Elsewhere Ted Kill and I have subjected international human rights law derived from all the sources enumerated in article 38 of the ICJ Statute to the necessary test in this regard and after a careful examination, we arrived at the conclusion that human rights do fulfill the three requirements. ${ }^{45}$ Of course, in an investor-state dispute, the parties to the dispute will never be identical with the parties to the investment agreement to be interpreted, because on one side we will always find a non-state actor. This obstacle can be overcome by reference to the Vienna Convention's definitions, under which 'party' means a State which has consented to be bound by the treaty and for which the treaty is in force. With regard to our investment agreements, it is therefore the States parties to these agreements which are the 'parties' for purposes of determining whether a rule applies under article 31(3)(c).

Let me give you just one illustration of the potential of the article in our context: it could have been used in the interpretation of the concept of 'discrimination' found in the Belgium/Luxembourg BIT with South Africa as applied in the recently-discontinued Foresti case. ${ }^{46}$ In this case, the claimants maintained that the Black Economic Empowerment legislation enacted by South Africa violated the non-discrimination obligations under the BIT. The relevant rules of international law capable of informing the interpretation of these obligations are to be found in the 1965 Convention on the Elimination of All Forms of Racial Discrimination (CERD), which recognizes in CERD article 1(4) that in circumstances where beneficial measures targeting certain groups are necessary in order to ensure that these groups are capable of exercising equal rights and freedoms, such positive discrimination will not constitute 'racial discrimination' as prohibited by CERD. More than that, CERD article 2(2) imposes an obligation on States to take such measures if the circumstances so warrant. Because CERD addresses the issue of (non-)discrimination for more than 170 States parties, it is appropriate to employ the definition in CERD for the interpretation of similar non-discrimination standards, like the one contained in our BIT. CERD articles 1(4) and 2(2) are both relevant rules in the interpretation of the non-discrimination provisions of the two BITs in question (the 1998 Benelux-South Africa BIT, and the 1997 Italy-South Africa BIT), more so since South Africa was well aware of the content of its non-discrimination obligations under CERD at the time that it ratified the two BITs, and could not be presumed to have deviated from such content without clear treaty language to that effect. South Africa signed

45 See (n 33) 695-707.

46 Piero Foresti and others $v$ The Republic of South Africa, ICSID Case No. ARB(AF)/07/1, Award 4 August 2010, http://icsid.worldbank.org/ICSID/FrontServlet?requestType=CasesRH\& actionVal=showDoc\&docId=DC1651_En\&caseId=C90 $>$ accessed 3 May 2011. 
CERD on 3 October 1994, and ratified the Convention on 10 October $1998 .^{47}$ South Africa signed both BITs before CERD entered into force (the BeneluxSouth Africa BIT entered into force on 14 March 2003, while the Italy-South Africa BIT entered into force on 16 March 1999). ${ }^{48}$ At the time South Africa signed both BITs, and even pending its ratification of CERD, South Africa was arguably under a duty not to defeat the object and purpose of CERD, including its key definition of "non-discrimination", which specifically allows for positive discrimination to benefit groups to exercise equal rights. ${ }^{49}$ If South Africa intended to deviate from this fundamental CERD definition of "non-discrimination" in the subsequent "non-discrimination" provisions in the BITs, it should have employed precise language to that effect. Lacking such language, the CERD definition may be regarded as having accordingly informed South Africa's usage of "non-discrimination" in the BITs. For this reason, and absent contrary language in the BITs themselves, the CERD provisions in articles 1(4) and 2(2) may be deemed relevant to the interpretation of non-discrimination in the two BITs. I admit that the example of CERD applied to the Foresti scenario is relatively uncomplicated insofar as the States parties to the BITs involved became also parties to CERD. It is more complicated if such treaty membership does not overlap, though this challenge may be met by resorting to the concept of obligations erga omnes. ${ }^{50}$

\section{The Integration of Economic and Social Rights}

But how about the obligations arising for States from economic and social rights? How would they fare within the matrix of article 31(3)(c), particularly with regard to the element of 'applicability in the relations between the parties' to an investment treaty dispute? This question is of fundamental importance in our present context because, aside from non-discrimination law, it will be economic and social rights that will occupy a prominent place in foreign investment disputes, put forward as defenses on the part of host States accused of BIT violations.

Fortunately, participation in the International Covenant on Economic, Social and Cultural Rights is almost as widespread as that in $\mathrm{CERD}^{51}$ and we

${ }^{47}$ For the status of CERD ratifications, see http://www2.ohchr.org/english/law/cerd.htm (last visited 29 June 2011).

${ }^{48}$ Luke Eric Peterson, South Africa's Bilateral Investment Treaties: Implications for Development and Human Rights, IISD Occasional Papers No. 26 (November 2006), at http:// library.fes.de/pdf-files/iez/global/04137-20080708.pdf (last visited 29 June 2011).

49 Article 18 of the Vienna Convention on the Law of Treaties.

${ }^{50}$ See further discussion in Simma and Kill (n 33) 701-702.

51 International Covenant on Economic, Social and Cultural Rights, 19 December 1966, United Nations, Treaty Series, vol. 993, p. 3, <http://www2.ohchr.org/english/law/cescr.htm > accessed 30 April 2011. The Covenant [hereafter 'ICESCR'] has been ratified or acceded to by 160 States Parties. <http://treaties.un.org/Pages/ViewDetails.aspx?src=TREATY\&mtdsg no $=I V-3 \&$ chapter $=4 \&$ lang $=$ en $>$ accessed 30 April 2011. International Convention on the Elimination of All Forms of Racial Discrimination, 21 December 1965, United Nations, Treaty 
will thus for most practical purposes be on the relatively safe ground of finding treaties on both sides of the equation, as it were. If this were not the case, recourse to the concept of obligations erga omnes might still help us to secure economic and social human rights law as 'rules of international law applicable in the relations between the parties'. 52

Let me now turn to the Economic and Social Covenant as a set of relevant rules within the meaning of article $31(3)(\mathrm{c})$, that is, applicable in the relations between the States parties to an investment dispute, and let me try to render it 'operational', so to speak. In this regard let us proceed from article 2(1) of the Covenant which enshrines the obligation of States parties 'to take steps, individually and through international assistance and co-operation, especially economic and technical, to the maximum of its available resources, with a view to achieving progressively the full realization of the rights recognized in the present Covenant by all appropriate means, including particularly the adoption of legislative measures. ${ }^{, 53}$ This is the Covenant's Grundnorm, the key to correctly decipher, as it were, its normative content.

What a state-of-the-art interpretation of article 2(1) does show is that, while the Covenant provides for progressive realization and acknowledges resource constraints, it also imposes certain obligations which are of immediate effect: to take deliberate and targeted steps and use all appropriate means; these will include legislation, but also the provision of judicial remedies with respect to rights which may be considered justiciable. ${ }^{54}$ The principal obligation of result reflected in article 2(1) is that of 'progressive realization', which imposes an obligation to move as expeditiously and effectively as possible towards full realization of the Covenant rights. In the monitoring practice of the Committee overseeing the implementation of the treaty, great emphasis has been put on the concept of 'minimum core obligations', to ensure the satisfaction of, at the very least, minimum essential levels of each of the rights. Where the available resources are demonstrably inadequate, a State party must still strive to ensure the widest possible enjoyment of the relevant rights under the prevailing circumstances. Thus the basic philosophy of the Covenant, as developed in General Comment 3 adopted by the Committee on Economic, Social and Cultural Rights in $1990,{ }^{55}$ one of the first, and in my view the most important of these General Comments, of which we have 21 at the moment,

Series, vol. 660, p. 195 < http://www.unhcr.org/refworld/docid/3ae6b3940.html> accessed 3 May 2011. CERD has 174 Parties. <http://reaties.un.org/pages/ViewDetails.aspx?src= TREATY\&mtdsg_no=IV-2\&chapter=4\&lang=en $>$ accessed 3 May 2011.

52 Under conditions discussed in Simma and Kill (n 33).

53 See P Alston and G Quinn, 'The Nature and Scope of States Parties' Obligations under the International Covenant on Economic, Social, and Cultural Rights' (1987) 9 Hum Rts Q 156, $166-171$.

${ }^{54}$ Committee on Economic Social and Cultural Rights (CESCR) General Comment No. 3, The nature of States parties obligations (art 2, para 1), 14 December 1990, available at < http:// www.unhchr.ch/tbs/doc.nsf/(Symbol)/94bdbaf59b43a424c12563ed0052b664?Opendocument $>$ accessed 15 April 2011. 
some of them highly relevant in our present context. ${ }^{56}$ In such General Comments, the UN human rights treaty bodies set out their understanding of the rights recognized in the various conventions and of the ensuing obligations on States parties. These Comments do not constitute an authentic interpretation of 'their' treaties (this would be up to the States parties acting in agreement, but this they never do), but the reading of treaty rights and obligations by the supervisory bodies enjoys considerable authority. Maybe we could gauge such authority by saying that States parties are to consider these enunciations in good faith. ${ }^{57}$

To help us along further, the theory and practice particularly of economic and social human rights has developed a specific method for the correct reading of these rights. It consists in the 'translation', so to speak, of the Covenant rights into correlative obligations on States parties. These obligations are grouped in three categories: obligations to respect, to protect, and to provide. ${ }^{58}$ Let me give you a few examples of such obligations relevant in the context of foreign investment protection and arbitration:

As to obligations of respect, in the Committee's General Comment 14, 'the failure of the State to take into account its legal obligations regarding the right to health when entering into ... agreements with [among others] ... multinational corporations' is listed as an example of a way in which a State party to the Covenant could violate its obligation to 'respect' the right to health. ${ }^{59}$ These obligations of respect can thus inform the analysis of 'health' and 'environment' exceptions clauses in many BITs and IIAs. ${ }^{60}$

${ }^{56}$ For a compilation of the relevant instruments and general comments, see General Comment Nos. 1-21 of the Committee on Economic, Social and Cultural Rights in < http://www2.ohchr. org/english/bodies/cescr/comments.htm > accessed 3 May 2011. See also P Alston and J Heenan, Economic, social, and cultural rights: a bibliography (Brill, Leiden, 2008); S Leckie and A Gallagher, Economic, Social, and Cultural Rights: A Legal Resource Guide (University of Pennsylvania Press, Philadelphia, 2006).

57 See M Schmidt, 'Follow-up Activities by UN Human Rights Treaty Bodies and Special Procedures Mechanisms of the Human Rights Council' in A de Zayas, Bertrand G Ramcharan, Jo Grimheden, Gudmundur Alfredsson (eds), International Human Rights Monitoring Mechanisms: Essays in Honour of Jakob Th. Möller (Brill $2^{\text {nd }}$ ed. 2009); Philip Alston, 'Out of the Abyss: The Challenges Confronting the New U.N. Committee on Economic Social and Cultural Rights' (1987) 9 Hum Rts Q 335; A Eide, 'Economic, Social and Cultural Rights as Human Rights' in A Eide, C Krause, A Rosas (eds), Economic Social and Cultural Rights (Martinus Nijhoff Publishers, The Hague, 2001).

58 See C Puta-Chekwe and N Flood, 'From Division to Integration: Economic, Social, and Cultural Rights as Basic Human Rights' I Merali and V Oosterveld (eds), Giving Meaning to Economic Social and Cultural Rights (Univ. of Pennsylvania Press, 2001) 39-51. For a detailed analysis of the historical and conceptual evolution of the tripartite typology of obligations under the Covenant, see M Sépulveda, The Nature of the Obligations under the International Covenant on Economic Social and Cultural Rights (Intersentia, Mortsel, 2003) 157-248.

59 General Comment No. 14 (2000), The right to the highest attainable standard of health (article 12 of the International Covenant on Economic, Social and Cultural Rights), E/C.12/2000/ 4, 11 August 2000, para. 50 < http://daccess-dds-ny.un.org/doc/UNDOC/GEN/G00/439/34/PDF/ G0043934.pdf?OpenElement $>$ accessed 15 April 2011.

60 See United Nations Conference on Trade and Development, Investor-State Dispute Settlement and Impact on Investment Rulemaking (2007) 76. 
Turning to obligations to protect, according to the same General Comment, the right to health under the Covenant would be violated by 'the failure to regulate the activities of ... corporations so as to prevent them from violating the right to health of others; the failure to protect consumers and workers from practices detrimental to health, e.g., by employers and manufacturers of medicine or food; the failure to discourage production, marketing and consumption of tobacco, narcotics and other harmful substances; $\ldots$ and the failure to enact or enforce laws to prevent the pollution of water, air and soil by extractive and manufacturing industries. ${ }^{61}$ General Comment 15 provides an illustrative list of the ways in which a State party could violate its obligations under the right to water. $^{62}$ A State party's '[f]ailure to effectively regulate and control water services providers' would thus breach that State's obligation to 'protect' the right to water ${ }^{63}$ Covenant obligations to protect can help inform the characterization of 'creeping or indirect expropriations', where Methanex and Sedco (awards that affirm the host State's police powers for environmental or social welfare-related objectives) stand against Metalclad, Tecmed, and Compania de Desarrollo de Santa Elena (that is, awards focusing solely on the impact of regulatory measures as 'substantial deprivation of investment', disregarding social welfare or environmental objectives). ${ }^{64}$ Covenant obligations to protect can also inform the interpretation of elements like 'public purpose', 'non-discrimination', and 'just compensation' in lawful regulatory takings, ${ }^{65}$ similarly to the approach taken in the

61 See (n 59) para 51.

62 General Comment No. 15 (2002), The right to water (arts 11 and 12 of the International Covenant on Economic, Social and Cultural Rights), E/C.12/2002/11, 20 January 2003, < http:// daccess-dds-ny.un.org/doc/UNDOC/GEN/G03/402/29/PDF/G0340229.pdf?OpenElement > accessed 15 April 2011. 63 ibid para 44(b)(ii).

${ }^{64}$ Methanex $v$ United States, UNCITRAL Case No. ARB/98/3 (2005), at Part IV, Chapter D, p 7; Sedco Inc v Iran, 9 Iran-US Claims Tribunal Reports; Tecnicas Medioambientales Tecmed SA v. Mexico, ICSID Case No ARB (AF)/00/2, Award, 29 May 2003; Feldman v Mexico, ICSID Case No. ARB(AF)/99/1, Award on the Merits, 16 December 2002. See also MTD Equity Sdn Bhd \& MTD Chile SA Chile v Chile, ICSID Case NoARB/01/7, Decision on Annulment of the ad hoc committee, 21 March 2007; Saluka Investments BV v Czech Republic (Saluka case), PCA, UNCITRAL, Partial Award 17 March 2006; Metalclad v Mexico, ICSID Case No. ARB (AF)/97/ 1, Award on the Merits, 16 December 2002; Tecmed SA v Mexico, supra; Compania de Desarrollo de Santa Elena SA v Costa Rica, ICSID Case No. ARB/96/1, Award on the Merits, 17 February 2000, para. 72.

65 See U Kriebaum, 'Is the European Court of Human Rights an Alternative to Investor-State Arbitration?' in Dupuy, Francioni \& Petersmann (n 12) 219-245; U Kriebaum, 'Regulatory Takings: Balancing the Interests of the Investor and the State' (2007) 8 Journal of World Investment \& Trade 717-744; Ronald Lauder $v$ Czech Republic, UNCITRAL Award, 3 September 2001, para 292; Mondev International Ltd v United States of America, ICSID Case No ARB(AF)/99/2, Final Award, 11 October 2002, at para 116; European Convention of Human Rights, Article 1 of Protocol I ('Every natural or legal person is entitled to the peaceful enjoyment of its possessions. No one should be deprived of his possessions except in the public interest and subject to the conditions provided for by the law and by the general principles of international law. The proceeding provisions shall not, however, in any way impair the right of a state to enforce such laws as it deems necessary to control the use of property in accordance with the general interest or to secure the payment of taxes or other contributions or penalties.'); Himpurna 
Mondev award which looked to the European Court of Human Rights' interpretation of 'public purpose' in relation to the European Convention. ${ }^{66}$

Let me illustrate the Covenant's obligations to provide by returning to what the Committee in its General Comment 3 has called 'minimum core obligations' ${ }^{67}$ It is stated there that 'in order for a State party to be able to attribute its failure to meet at least its minimum core obligations to a lack of available resources, it must demonstrate that every effort has been made to use all resources that are at its disposition in an effort to satisfy, as a matter of priority, those minimum obligations ... Even in time of severe resources constraints, whether caused by a process of adjustment, of economic recession, or by other factors, the vulnerable members of society can and indeed must be protected by the adoption of relatively low-cost targeted programmes. ${ }^{, 68}$ This last statement might be of relevance in Argentina's pending arbitrations, if it could be shown that such 'minimum core obligations' can be read into the particular language of BIT provisions on national emergency and necessity. ${ }^{69}$

According to General Comment 15, a State's obligation to fulfill its population's human right to water could be breached by, among other things, the 'failure of a State to take into account its international legal obligations regarding the right to water when entering into [international] agreements' ${ }^{70}$ This Comment could inform the interpretation of the scope of 'investment', which does not recognize an absolute right of establishment or admission of foreign investment, unless so provided in the treaty in question. ${ }^{71}$

In conclusion of this short tour d'horizon through the normative substance of economic and social rights recognized in the Covenant as they could inform the interpretation of investment treaties by arbitral tribunals qua article $31(3)(c)$, let me repeat that, while the reading of the obligations on

California Energy Ltd. (Bermuda) v PT (Gersero) Perusahaan Listruik Negara, 14(12) Mealey's International Arbitration Report A-1 (1990) A-50.

${ }^{66}$ Mondev International Ltd v United States of America, ICSID Case No. ARB/(AF)/99/2, Award of October 11, 2002, para 144.

67 See (n 54) para 10

68 ibid paras 10 and 12.

69 See interpretative controversies in LG\&E Energy Corp v Argentina, Decision on Liability, ICSID Case No ARB/02/1 (3 October 2006); LG\&E Energy Corp v Argentina, Award, ICSID Case No ARB/02/1 (July 25, 2007); Cont'l Cas Co v Argentina, Award, ICSID Case No ARB/03/ 9, Sept 5, 2008; Sempra Energy International v Argentine Republic, ICSID Case No. ARB/02/16, Decision on the Argentine Republic's Request for Annulment of the Award, 29 June 2010; Enron $v$ Argentine Republic, ICSID Case No. ARB/01/3, Decision on the Argentine Republic's Request for Annulment of the Award, 30 July 2010; DA Desierto, 'Necessity and 'Supplementary Means of Interpretation of Non-Precluded Measures in Bilateral Investment Treaties' (2010) 31 Un Pa J Int'l L 3, 827-934.

70 See (n 62) para 44(c)(vii).

71 Mihaly International Corporation v Democratic Socialist Republic of Sri Lanka, ICSID Case No ARB/00/2 (1999); Zhinvali Development Limited v Georgia, ICSID Case No ARB/00/1, unpublished. See also Fedax NV v Republic of Venezuela, ICSID Case No ARB/96/3 (1998), which involved promissory notes; Cesoslovenska Obchodni Banka AS v The Slovak Republic, ICSID Case No ARB/97/4 (1999), which involved a financing loan extended as part of a government's privatization program; Joy Mining Machinery Limited v. The Arab Republic of Egypt, ICSID Case No. ARB/03/11, Award of 6 August 2004, at paras 49-50; Salini Costruttori SpA and Italstrade SpA v Kingdom of Morocco, Jurisdiction, (2001) 6 ICSID Rep 398. 
States parties as developed by the Covenant Committee is not legally binding per se, it does express the understanding of these obligations reached after careful consideration by the body possessing the highest authority to do so. In my view, if an investment tribunal confronted with a Covenant matter neglected to consider these pronouncements, its reasoning with regard to that matter would be insufficient - with all the consequences attached to this default.

\section{A Meaningful Follow-up to Systemic Integration of Human Rights}

Let us now have a look at what will happen once an investment tribunal has interpreted a clause of the agreement in question à la article 31(3)(c), that is, duly taking cognizance of a rule of international human rights law invoked by the host State. That State will have used the obligations flowing from these human rights as a defense. The question will then become one of competing obligations. Let us assume that the tribunal has found human rights obligations of the host State applicable to the case at hand. What we will then discover is that this was in many ways the easiest and least consequential among several further steps that we must explore if international human rights law is to interact meaningfully with international investment law. Once a tribunal has before it the applicable human right norms, it must decide whether or how these rules affect the arguments advanced by the parties. If 'fair and equitable treatment' properly understood includes a balancing of obligations, including those arising from human rights, are a State's obligations to its own population to be weighed against investor rights under BITs? How can we harmonize the host State's obligations under the two regimes? This will always be a difficult exercise and sometimes compliance with both set of obligations will be virtually impossible. At this point, what might assist us could perhaps be the policy motivations animating human rights on one hand and investor rights on the other. In this regard, a report of the (former) UN Commission on Human Rights submitted in 2003 noted that, while human rights are 'fundamental' to human dignity, investment rights are 'instrumental' to the achievement of certain policy objectives which, presumably, are not indispensable for human dignity. ${ }^{72}$ This would speak in favor of granting priority to the host State's human rights obligations, particularly where 'minimum core' obligations are affected.

As suggested in our discussion of article 31 (3)(c), however, in the determination of the weight to be given to human rights norms, the degree to which these norms, as external rules, are 'relevant' should also be considered. In saying this, I am not suggesting that human rights law can influence the

72 Report of the High Commissioner for Human Rights, Human rights, trade and investment, E/CN/4/Sub.2/2003/9, 2 July 2003, para $24<$ http://daccess-dds-ny.un.org/doc/UNDOC/GEN/ G03/148/47/PDF/ G0314847.pdf?OpenElement > accessed 15 April 2011. 
international investment regime only by means of what I called 'external rules' informing treaty interpretation. The Award in Biwater Gauff $v$ Tanzania shows that other considerations, such as the responsibilities of foreign investors, also have a role to play. ${ }^{73}$ But, as I have indicated, here is not the place to address these. What should have become clear, however, is that, if there were ways of harmonizing the obligations of a host State towards a foreign investor and those arising under international human rights law outside - or instead of - litigation in the first place, these possibilities ought definitely to be explored, and vigorously. I have already drawn attention to certain recent innovations in investment treaty design which might take the just described problematique of economic and social rights and obligations better into account. But I also recognize that these new approaches essentially still represent post-establishment strategies which will be contingent upon the success of treaty interpretation in the dispute settlement phase. Further, the 'public-private' divide in these cases will endure, between those who will assert public interests through human rights, and those who will defend the settled autonomy or normative specialization of international investment law. For this reason I now turn to a less explored, and possibly more viable, strategy: that of designing compliance with the obligations under internationally guaranteed economic and social rights within the intra-State level of the foreign investment contract between the host State and the investor. In other words, I turn now to the second entry point for human rights in the modern investment regime: the recasting of the investors' 'legitimate expectations' under foreign investment contracts.

IV. THE SECOND ENTRY POINT FOR HUMAN RIGHTS IN THE MODERN INVESTMENT REGIME: RECASTING INVESTORS' 'LEGITIMATE EXPECTATIONS' UNDER FOREIGN INVESTMENT CONTRACTS

\section{A. The Investor's 'Legitimate Expectations'}

Arbitral tribunals have consistently recognized that a breach of the foreign investment contract and a breach of the underlying investment agreement constitute separate causes of action. ${ }^{74}$ Even umbrella clauses will not always elevate all contractual breaches to the level of inter-state treaty breaches. ${ }^{75}$

73 Biwater Gauff v Tanzania, ICSID Case No ARB/05/22, Award, 24 July 2008, < http:// icsid.worldbank.org/ICSID/FrontServlet?requestType=CasesRH\&actionVal=showDoc\&docId= DC770_En\&caseId=C67 > accessed 15 April 2011.

74 United Nations Conference on Trade and Development, Investor-State Dispute Settlement and Impact on Investment Rulemaking (2007) 26. See SGS Societé Générale de Surveillance SA v Islamic Republic of Pakistan, International Arbitration Report, Vol 18, \# 9, September 2003, in contrast to SGS Societé Générale de Surveillance SA v Republic of the Philippines, ICSID Case No ARB/02/6, Decision of the Tribunal on Objections to Jurisdiction, January 29, 2004.

${ }^{75}$ See S Leader, 'Human Rights, Risks, and New Strategies for Global Investment' (2006) 9 Journal of International Economic Law 3. 
For this reason, foreign investment contracts represent a separate entry point for mediating compliance with internationally guaranteed economic and social rights. As we have seen from the interpretative controversies on investment treaty protection versus the host State's exercise of police power and regulatory authority for human rights and public policy objectives, it is clear that the pre-establishment information available to the foreign investor at the time of the conclusion of the investment contract will be critical to the determination of his 'legitimate expectations'. ${ }^{76}$ In the words of the Tecmed Award: '[t]he foreign investor expects the host State to act in a consistent manner, free from ambiguity and totally transparently ... so that it may know beforehand any and all rules and regulations that will govern its investments. ${ }^{77}$ For the most part, stabilization clauses, at the level both of the investment treaty and of the foreign investment contract, are to ensure such regulatory predictability and transparency to both the foreign investor and the host State. ${ }^{78}$

76 'Legitimate expectations of investors' are a crucial element in determining a host State's breach or compliance with the fair and equitable treatment (FET) standard in international investment treaties. Tecmed $v$ Mexico introduced the concept of 'basic expectations that were taken into account by the foreign investor to make the investment', as part of the calculus of elements to determine breach or compliance with the FET standard. (Tecmed v Mexico (n 64) para 154.) The arbitral tribunal in CMS Gas accepted the Tecmed $v$ Mexico characterization of investor expectations as a requirement involving regulatory consistency and transparency: "[ $\mathrm{t}$ ] he foreign investor expects the host State to act in a consistent manner, free from ambiguity and totally transparently in its relations with the foreign investor, so that it may know beforehand any and all rules and regulations that will govern its investments.' CMS Gas (n 21) paras 273-277. For the most part, this element has been treated as an open-textured phrase left to the subjective determination of arbitrators according to the circumstances of each case. The FET clause in NAFTA Article 1105 has accepted some innovations into the determination of investor expectations through the NAFTA Commission's 31 July 2001 Note of Interpretation, which dissociates the FET clause from the 1920s Neer claims standard requiring prior proof of a State's bad faith, before it may be deemed to have violated the international minimum standard in the treatment of aliens within its territory. Note of Interpretation of the NAFTA Free Trade Commission, 31 July 2001, < <ttp://www.international.gc.ca/trade-agreements-accords-commerciaux/disp-diff/ NAFTA-Interpr.aspx?lang=en $>$ accessed 4 May 2011; Neer Claim, United Nations Reports of International Arbitral Awards (1926), IV, p 60-61. Accordingly, the tribunal in GAMI Investments Inc $v$ Mexico held that '[a] claim of maladministration would likely violate [NAFTA] Article 1105 if it amounted to an 'outright and unjustified repudiation' of the relevant regulations.' GAMI Investments Inc v Mexico, UNCITRAL, Final Award, 15 November 2004, para 103.

77 Tecmed award (n 64) para 154.

78 Stabilization clauses may take the form of intangibility clauses (which state that the contract can only be modified with the consent of the parties); freezing clauses (which provide that the applicable domestic law for the contract is frozen in time as the law in force at the date of the conclusion of the contract, and which cannot be affected by subsequent legislation inconsistent with that initial body of law); consistency clauses (which apply future domestic legislation of the host State only if it is consistent with the investment contract); fiscal or tariff stabilisation clauses (which fix the host State's tax or tariff regimes affecting the investment); and economic equilibrium clauses (which link the alteration of the terms of the contract to the possibility of periodic contractual renegotiation, to restore, as closely as possible, the original economic guarantees of the contract). These clauses are meant to cure the information asymmetry between foreign investors and host States. See L Cotula, 'Foreign Investment Contracts' (August 2007) International Institute for Environment and Development Briefing Paper No. 4. 


\section{B. My Proposal: A Human Rights Audit}

In my view, economic and social rights should not be regarded as harbingers of regulatory uncertainty to the contractual environment of the foreign investor and the host State. Hence, why not undertake a proper assessment of the host State's pre-establishment regulatory information by including a Human Rights Audit as part of the due diligence to be conducted by the investor and the host State? Such an audit would be in keeping with the transparency regulations that we find in some of the new generation of investment agreements. ${ }^{79}$ The 'human rights audit' as I envisage it would not be the same as some NGO-based proposals for 'human rights impact assessments' ${ }^{80}$ Those are of a much broader scope, spanning inter-disciplinary approaches, very detailed and fact-intensive. What I propose for a 'human rights audit' is a more modest exercise which, to some degree, is already being undertaken voluntarily in the context of social responsibility review within corporations and financing institutions. In our present context, parties could develop a legal analysis of the host State's police powers within its constitutional framework and determine its subject-matter coverage and limitations, as well as any specific commitments of the host State to refrain from particular regulation in a given economic activity. The 'human rights audit' would be a joint undertaking of foreign investors and host States, to survey the host State's human rights treaty commitments (especially in the field of economic and social rights) and methods for implementing such commitments (such as doctrines of incorporation or transformation, or Charming Betsy-type interpretative rules) ${ }^{81}$ as well as to provide investors with continuing access to the host State's periodic reports to the human rights treaty bodies, especially the Committee on Economic, Social and Cultural Rights, plus the Committee's concluding observations on the host State's performance. The audit would result in an analysis of the domestic status of international treaty norms on economic and social rights and of the law implementing them within the prospective host State's constitutional system, and more importantly, of whether (and if so, to what degree) such norms are susceptible to future amendments through public regulations, judicial interpretation, or legislative enactment. $^{82}$

The primary objective of the 'human rights audit' would thus be to fully include the prospective host State's international obligations resulting from

79 See Canada 2004 Model BIT, art 19.

80 S Walker, 'Human Rights Impact Assessments of Trade-Related Policies', in MW Gehring and M Claire Cordonier-Segger, Sustainable Development in World Trade Law (Kluwer Law, The Hague, 2005) 217-256.

81 Murray $v$ The Charming Betsy 6 US (2 Cranch 64) (1804): 'It has also been observed that an act of Congress ought never to be construed to violate the law of nations if any other possible construction remains...'

${ }^{82}$ See sample standard stabilization clauses in production sharing agreements and concession contracts in Bishop, Crawford, \& Reisman (n 25) 286-307. 
economic and social rights as part of the body of applicable law. The audit would introduce at the level of the foreign investment contract what is already being done in some of the new generation of international investment agreements. What we find there are annexes of 'non-conforming measures' (which bind the level of conformity existing between the domestic legislation of the contracting parties and the obligations of the agreement at the time of the conclusion of the agreement) $;^{83}$ as well as annexes of permitted 'inconsistent' measures (which list economic activities or sectors where the contracting parties may maintain or adopt measures inconsistent with one or several obligations of the agreement). ${ }^{84}$ The ultimate result of conducting a 'human rights audit' would be a better definition of the landscape of the foreign investor's 'legitimate expectations' in a way that would not leave excessive ex post discretion to arbitrators, should investor-host State disputes arise in the future. On the one hand, foreign investors would be able to better estimate and prepare for alternative scenarios of regulatory measures which the host State might take to vindicate its economic and social human rights obligations, and on the other, host States would not be unduly constrained from defining their public policy agenda as a result of investment protection guarantees within foreign investment contracts and their corresponding treaties.

A 'human rights audit' as suggested here would not impose extraordinary transaction costs so as to be prohibitive against the entry of foreign investment. Various features of the modern international investment regime already recognize and voluntarily build in some degree of social impact review. Foreign investors conduct legal due diligence as a matter of course, in relation to a host State's trade and investment policy programmes, in order to better enable them to estimate the political risk (and if necessary, take out political risk insurance against their investment), and ultimately to come up with the most accurate 'price' of their capital infusion into a host State. ${ }^{85}$ Most of the large international financial institutions, banking groups, and other lending facilities to foreign investors subscribe to the Equator Principles, which commit such institutions to desist from financing projects where the prospective investor-borrower will not, or is unable to, comply with international standards, especially the environmental, health, and safety guidelines used by the International Finance Corporation and the World Bank. ${ }^{86}$ Some host States include, as part of the governmental prospectuses accompanying their offer sheets/invitations to bid, some reference to pertinent regulatory

83 See 2003 Japan-Vietnam BIT, art 6.

84 See Chile-Korea Free Trade Agreement, Chapter on Investment, art 10.9.

85 On the conceptual and empirical assessment of political or regulatory risk, see WJ Henisz, Politics and International Investment: Measuring Risks and Protecting Profits (Edward Elgar Publishing Limited, Kent, 2002) 5-27; P Harms, International Investment, Political Risk, and Growth (Kluwer Law, The Hague, 2000) 57-114.

${ }^{86}$ See the July 2006 Equator Principles <http://www.equator-principles.com > accessed 15 April 2011. 
information. ${ }^{87}$ Finally, host States and foreign investors arrange for internal monitoring and control mechanisms, such as regulatory compliance boards and voluntary contractual undertakings not to invoke broad stabilization clauses when these would prevent the host State from adopting regulations that implement obligations under international human rights treaties. ${ }^{88}$ Considering these examples, a 'human rights audit' should not be seen as a radical departure from industry benchmarks in the international investment regime. On the contrary, a 'human rights audit' should be deemed a necessary, prudent, and responsible measure by both private lawyers advising foreign investors as well as legal advisers of host State governments.

I submit that institutionalizing the practice of human rights auditing would be more efficient in defining the 'investment-backed legitimate expectations' known to both the foreign investor and the host State. This level of cooperation at the intra-state contractual level could better foster the guarantees of investment protection alongside the host State's compliance with international economic and social rights, in a manner that does not have to leave either purpose to the uncertain vagaries of mere 'compensability' in the dispute settlement phase between host States and foreign investors. This preestablishment strategy, focusing on foreign investment contract review and due diligence, could usefully complement the post-establishment entry of human rights treaty norms through investment treaty interpretation. Sharpening both our contract drafting as well as treaty drafting skills with due sensitivity to economic and social human rights, could better achieve the desired balance of precision and flexibility in host State regulation and investor protection in the 'evolving' modern international investment regime.

87 See 'Chapter 2: Petroleum Agreements and Bidding' in F Jahn, M Cook, M Graham (eds), Hydrocarbon Exploration and Production (Elsevier Science, 2011).

${ }_{88}$ Cotula (n 78). See also L Cotula, 'Reconciling regulatory stability and evolution of environmental standards in investment contracts: Towards a rethink of stabilization clauses' (2008) 1 Journal of World Energy Law \& Business 2, 158-179. 
Copyright of International \& Comparative Law Quarterly is the property of Cambridge University Press and its content may not be copied or emailed to multiple sites or posted to a listserv without the copyright holder's express written permission. However, users may print, download, or email articles for individual use. 